\title{
Perbedaan Kualitas Seksual pada Wanita Akseptor KB Hormonal dengan KB Non-Hormonal
}

\author{
Winda Nurmayani ${ }^{1}$, Misroh Mulianingsih ${ }^{2 *}$, Ni Ketut Ika Mustika Suarnaya ${ }^{3}$ \\ ${ }^{1,2,3}$ Prodi S1 Keperawatan, STIKES Yarsi Mataram \\ *Email: misroh.yarsi@gmail.com
}

\begin{abstract}
Background: Sexual intercourse in the family is the peak of harmony, therefore both parties must be able to enjoy it together. Sex dissatisfaction can lead to differences of opinion, disputes and ultimately divorce. Hormonal contraception has side effects, one of which is an imbalance of the hormones estrogen and progesterone which can cause changes in sexual activity. Each type of family planning has its own side effects, but in most cases a decrease in sexual desire is a side effect that can be found in every use of the type of family planning. The purpose of this study was to determine differences in sexual quality in female hormonal and non-hormonal family planning acceptors. Methods: Descriptive analytic type of research with a comparative design using the Case Control approach, a sample of 68 Wus which is a hormonal and non-hormonal family planning acceptor. Simple Random Sampling sampling technique and observation sheet instrument and SQOL-F questionnaire. This research uses Chi Square data analysis. Results: Chi Square Continuity Corrections test results showed significant results $P=0.000(P<0.1)$, meaning that $P$ value 0.000 is smaller than 0.1 there are differences in sexual quality in female hormonal and non-hormonal KB acceptors. Conclusion: Most non-hormonal family planning acceptors have good sexual qualities while hormonal birth control acceptors mostly have moderate sexual quality.
\end{abstract}

Keywords: contaception acceptors, sexual quality, birth control

\section{PENDAHULUAN}

Hubungan seksual dalam keluarga merupakan puncak keharmonisan dan kebahagiaan, oleh karena itu kedua pihak harus dapat menikmatinya bersama. Ketidakpuasan seks dapat menimbulkan perbedaan pendapat, perselisihan dan akhirnya perceraian (Manuaba, 2010). Seks adalah fungsi utama manusia dan memiliki peran mendasar dalam kehidupan reproduksi. Fungsi ini mengintegrasikan faktor fisik, emosional dan psikologis serta memengaruhi kualitas hidup (Katmini, 2020).

Menurut penelitian Shahraki et al., (2018), pada wanita infertilias dan wanita sehat atau subur di Teheran Iran, bahwa disfungsi seksual lebih sering terjadi pada wanita dengan infertilitas primer dari infertilitas sekunder dan sehat, kualitas hidup wanita subur secara signifikan lebih tinggi daripada individu yang tidak subur dan wanita dengan infertilitas sekunder memiliki skor yang lebih tinggi secara keseluruhan. Skor SQOL-F secara signifikan lebih rendah pada kasus dengan disfungsi seksual. Dalam studi sebelumnya, Millheiser et al., (2010), menemukan disfungsi seksual pada $25 \%$ kelompok subur dan $40 \%$ wanita tidak subur.

Masalah kesehatan seksual tidak terlalu diperhatikan, padahal kesehatan seksual mempengaruhi kesehatan umum dan masalah seksual mempengaruhi kualitas hidup secara negatif. Ada berbagai macam hal yang dapat menyebabkan menurunnya kualitas seksual pada wanita usia subur. Selain karena faktor penyakit, usia dan stres, konsumsi obat dan gangguan keseimbangan hormon juga dapat menjadi penyebab menurunnya kualitas seksual pada wanita usia subur. Gangguan 
keseimbang hormon ini dapat disebabkan oleh penggunaan alat kontrasepsi hormonal. Kontrasepsi hormonal mempunyai efek samping, salah satunya adalah ketidakseimbangan antara hormon estrogen dan progesteron yang dapat menyebabkan perubahan pada aktivitas seksual. Hal ini dikarenakan hormon progesteron yang terkandung dalam kontrasepsi hormonal memiliki efek kerja yang dapat menekan hormon estrogen sehingga mengakibatkan vagina menjadi kering dan dapat mengurangi sirkulasi androgen serta melemahkan peredaran testosteron yang memang diperlukan untuk memicu keinginan gairah seksual (Semararatih, 2010).

Peserta KB aktif diantara PUS tahun 2018 sebesar $63,27 \%$ hampir sama dengan tahun sebelumnya yang sebesar $63,22 \%$ (BKKBN, 2018). Jumlah PUS di Lombok Barat terdapat 149.188 pasangan. Pengguna metode suntikan sebesar $51.88 \%$, pil sebanyak $10,51 \%$ dan implant sebanyak 23,76\% (Profil Kesehatan NTB, 2018). Pada wilayah kerja Puskesmas Sedau terdapat sekitar 5.397 pasangan usia subur, hampir sebagian besar menggunakan KB hormonal dan sebagian kecil menggunakan KB Non-hormonal. Menurut data pada Puskesmas Sedau, untuk metode kontrasepsi hormonal terdapat 1.051 wanita menggunakan metode KB implant, 2.368 wanita menggunakan metode suntik, dan 194 wanita menggunakan metode KB pil. Pada metode kontrasepsi non-hormonal terdapat 418 wanita menggunakan metode IUD, 4 orang pria menggunakan metode KMP, 80 wanita menggunakan metode KMW dan 26 pasangan menggunakan kondom.

Topik tentang pernikahan tidak terlepas dari pembicaraan tentang hubungan intim pasangan, karena hubungan intim merupakah salah satu kebutuhan biologis individu. Hubungan seksual adalah faktor penting untuk menjaga keharmonisan dan kebahagiaan rumah tangga. Masalah yang terjadi karena hubungan seksual bisa menjadi salah satu faktor yang membuat hubungan memburuk dan tak jarang terjadi perceraian. Menurut data Mahkamah Agung tahun 2018 sebanyak 419.268 pasangan suami istri bercerai di Indonesia.

Penggunaan KB hormonal memiliki efek samping yang dapat menurunkan libido seksual sehingga akan berdampak pada kualitas kehidupan dan kepuasan seksual pasangan suami istri (Pratiwi, 2018). Jika hal ini terus berlanjut dalam kehidupan rumah tangga makan akan berimbas kepada Kekerasan Dalam Rumah Tangga (KDRT). Data dalam catatan tahunan 2018, terkumpul data bahwa kasus KDRT/RP (ranah personal) sudah mencapai angka $71 \%$ (9.609). Kekerasan seksual adalah ranah pribadi yang menjadi terbanyak kedua yang paling banyak dilaporkan (Sari \& Sularto, 2019). Berdasarkan data dari P2TP2A, (2017), pada tahun 2016 tercatat 1.679 kasus KDRT dan meningkat pada tahun 2017 menjadi 1.821 kasus KDRT. Dari data tersebut dipaparkan bahwa $70 \%$ kasus yang dilaporkan adalah kasus kekerasan seksual (Masnun, 2019).

Studi pendahuluan peneliti dengan cara wawancara yang didampingi oleh kader kepada 20 orang wanita usia subur (WUS) di wilayah kerja Puskesmas Sedau yang telah menikah dan menggunakan KB hormonal mereka mengaku tidak begitu menikmati hubungan seksual yang mereka lakukan dengan pasangannya. 9 dari 20 orang mengatakan merasakan kesakitan saat berhubungan intim dengan 
pasangannya, 7 orang mengatakan tidak mencapai titik orgasme saat berhubungan seksual dan 4 orang mengatakan jarang mendapatkan dorongan atau gairah untuk berhubungan seksual dengan pasangannya. Penelitian ini pernah dilakukan Yosin et al.,( 2016) dengan judul effect of hormonal contraceptive on sexual life, body mass index, skin health, and uterine bleeding, in women of reproduction age in Jombang, East Java, dengan hasil penelitian, penggunaan kontrasepsi hormonal suntik menurunkan kualitas kehidupan seksual, menurunkan kualitas kesehatan kulit, meningkatkan indeks massa tubuh, dan meningkatkan perdarahan uterus yang tidak normal persamaannya sama-sama meneliti kualitas seksual dan kontrasepsi hormonal dan non hormonal.

Perbedaan studi ini dengan penelitian terdahulu yaitu jenis penelitiannya. Penelitian terdahulu berbentuk observasional analitik dengan desain kohort retrospektif dan yang sekarang deskriptif analitik dengan desain Case Control. Tujuan penelitian ini untuk menganalisis perbedaan kualitas seksual pada wanita akseptor KB hormonal dengan KB non-hormonal.

\section{METODE PENELITIAN}

Penelitian ini adalah deskriptif analitik dengan menggunakan desain komparatif. Peneliti menggunakan pendekatan Case Control. Populasi dari penelitian ini adalah seluruh wanita akseptor KB berjumlah 216 pada 3 bulan terakhir (September, Oktober, November) di Desa Golong wilayah kerja Puskesmas Sedau Kabupaten Lombok Barat tahun 2019. Sampel pada penelitian ini sebanyak 136 orang akseptor KB yang memenuhi kriteria inklusi pada penelitian ini dengan rincian 68 untuk akseptor $\mathrm{KB}$ hormonal dan 68 orang untuk akseptor KB nonhormonal. Tehknik sampling yang digunakan dalam penelitian ini adalah simple random sampling dengan kriteria inklusi yaitu wanita usia subur (WUS) telah menikah dan berumur 20-30 tahun,aktif melakukan hubungan seksual,telah menggunakan KB (hormonal atau non-hormonal) minimal 1 tahun dan maksimal 2 tahun, dan bersedia di teliti. Kriteria eksklusi penelitian yaitu responden mengalami salah satu dari data berikut : dalam keadaan hamil, baru selesai masa nifas, sedang menghadapi permasalahan dengan pasangannya, gangguan psikologi (kecemasan), gangguan ginekologi (ada riwayat kelainan panggul). Penelitian ini dilaksanakan di wilayah Desa Golong, Kec.Narmada, Lombok Barat Tahun 2020.

Instrumen yang digunakan dalam penelitian ini adalah kuesioner The sexual quality of life-female (SQOL-F) oleh Pakpour et al., (2013) dimana pada kuesioner ini terdapat 18 pertanyaan tentang kualitas seksual wanita yang telah dimodifikasi oleh peneliti.Skor yang diberikan sesuai dengan jawaban yang diberikan dari pernyataan favorable dan unfavorable dengan item jawaban (selalu, sering, kadang-kadang dan tidak pernah). Selanjutnya dari 18 pertanyaan mengklasifikasikan kualitas seksual pada tiga tingkat : Baik (49-72), Sedang (2548) dan Buruk (18-24). Analisis data penelitian ini menggunakan analisis uni variat dengan analisa data Chi Square.

Dalam pelaksanaan penelitian sesuai dengan alur yang ada, penelitian ini telah mendapatkan izin dari Kesbangpol NTB, Bappeda NTB dan terakhir izin dari Pihak Puskesmas Narmada. Setelah memenuhi 
persyaratan, memberikan inform consent ke wanita yang memenuhi kriteria sampel penelitian untuk memberikan persetujuan kesediaannya menjadi responden.

\section{HASIL PENELITIAN}

Hasil penelitian

menunjukkan karakteristik wanita akseptor KB hormonal dan non-hormonal sebagai berikut:

Tabel 1.Distribusi Karakteristik Wanita Akseptor KB Hormonal dan Non-Hormonal

\begin{tabular}{|c|c|c|c|c|c|c|c|c|c|}
\hline \multirow{3}{*}{$\begin{array}{c}\text { Karakteristik } \\
\text { Responden }\end{array}$} & \multicolumn{6}{|c|}{ Kualitas seksual } & \multirow{3}{*}{$\mathbf{P}$} & \multirow{3}{*}{ OR } & \multirow{3}{*}{$90 \% \mathrm{Cl}$} \\
\hline & \multicolumn{2}{|r|}{ Baik } & \multicolumn{2}{|c|}{ Sedang } & \multicolumn{2}{|c|}{ Total } & & & \\
\hline & $\mathbf{N}$ & $\%$ & $\mathbf{N}$ & $\%$ & $\mathbf{N}$ & $\%$ & & & \\
\hline $\begin{array}{l}\text { Usia } \\
\text { - Beresiko }(<20->35 \text { th }) \\
\text { - tidak beresiko }(20-35 \text { th }) \\
\text { Total }\end{array}$ & $\begin{array}{l}34 \\
52 \\
86\end{array}$ & $\begin{array}{l}55,7 \% \\
69,3 \% \\
63,2 \%\end{array}$ & $\begin{array}{l}27 \\
23 \\
50\end{array}$ & $\begin{array}{l}44,3 \% \\
30,7 \% \\
36,8 \%\end{array}$ & $\begin{array}{r}61 \\
75 \\
136\end{array}$ & $\begin{array}{l}100 \% \\
100 \% \\
100 \%\end{array}$ & 0.111 & 0.557 & $\begin{array}{l}275- \\
1,127\end{array}$ \\
\hline $\begin{array}{l}\text { Usia menikah } \\
\bullet<21 \text { tahun } \\
\bullet>21 \text { tahun } \\
\text { Total }\end{array}$ & $\begin{array}{l}49 \\
37 \\
86\end{array}$ & $\begin{array}{l}62,0 \% \\
64,9 \% \\
63,2 \%\end{array}$ & $\begin{array}{l}30 \\
20 \\
50\end{array}$ & $\begin{array}{l}38,3 \% \\
35,1 \% \\
36,8 \%\end{array}$ & $\begin{array}{r}79 \\
57 \\
136\end{array}$ & $\begin{array}{l}100 \% \\
100 \% \\
100 \%\end{array}$ & 0,857 & 0.883 & $\begin{array}{l}435- \\
1.794\end{array}$ \\
\hline $\begin{array}{l}\text { Lama pernikahan } \\
-<5 \text { tahun } \\
\text { - > } 5 \text { tahun } \\
\text { Total }\end{array}$ & $\begin{array}{l}50 \\
36 \\
86\end{array}$ & $\begin{array}{l}58,1 \% \\
72,0 \% \\
63,2 \%\end{array}$ & $\begin{array}{l}36 \\
14 \\
50\end{array}$ & $\begin{array}{l}41,9 \% \\
28,0 \% \\
36,8 \%\end{array}$ & $\begin{array}{r}86 \\
50 \\
136\end{array}$ & $\begin{array}{l}100 \% \\
100 \% \\
100 \%\end{array}$ & 0.140 & 0.540 & $\begin{array}{c}0.255- \\
1.145\end{array}$ \\
\hline $\begin{array}{l}\text { Jumlah anak } \\
\text { - Primipara } \\
\text { - Multipara } \\
\text { Total } \\
\end{array}$ & $\begin{array}{l}48 \\
38 \\
86 \\
\end{array}$ & $\begin{array}{l}57,8 \% \\
71,7 \% \\
63,2 \% \\
\end{array}$ & $\begin{array}{l}35 \\
15 \\
50 \\
\end{array}$ & $\begin{array}{l}42,2 \% \\
28,3 \% \\
36,8 \% \\
\end{array}$ & $\begin{array}{r}83 \\
53 \\
136 \\
\end{array}$ & $\begin{array}{l}100 \% \\
100 \% \\
100 \% \\
\end{array}$ & 0.144 & 0.541 & $\begin{array}{c}0.258- \\
1,134\end{array}$ \\
\hline $\begin{array}{l}\text { Pendidikan } \\
\text { - PendidikanTinggi } \\
\text { - Pendidikan Sedang } \\
\text { - Pendidikan Rendah } \\
\text { Total } \\
\end{array}$ & $\begin{array}{r}29 \\
56 \\
1 \\
86\end{array}$ & $\begin{array}{l}60,4 \% \\
65,1 \% \\
50,0 \% \\
63,2 \% \\
\end{array}$ & $\begin{array}{l}19 \\
30 \\
1 \\
50\end{array}$ & $\begin{array}{r}39,6 \% \\
34,9 \% \\
50,0 \% \\
36,8 \\
\end{array}$ & $\begin{array}{r}48 \\
86 \\
2 \\
136 \\
\end{array}$ & $\begin{array}{l}100 \% \\
100 \% \\
100 \% \\
100 \% \\
\end{array}$ & 0.800 & & \\
\hline $\begin{array}{l}\text { Pekerjaan } \\
\text { - Tidakbekerja } \\
\text { - Bekerja } \\
\text { Total }\end{array}$ & $\begin{array}{l}48 \\
38 \\
86 \\
\end{array}$ & $\begin{array}{l}64,9 \% \\
61,3 \% \\
63,2 \% \\
\end{array}$ & $\begin{array}{l}26 \\
24 \\
50\end{array}$ & $\begin{array}{r}35,1 \% \\
38,7 \% \\
36,8 \% \\
\end{array}$ & $\begin{array}{r}74 \\
62 \\
136 \\
\end{array}$ & $\begin{array}{l}100 \% \\
100 \% \\
100 \% \\
\end{array}$ & 0,723 & 1.166 & $\begin{array}{c}579- \\
2.346\end{array}$ \\
\hline $\begin{array}{l}\text { Jenis KB } \\
\bullet \quad 1 \text { tahun } \\
\text { - } 2 \text { tahun } \\
\text { Total }\end{array}$ & $\begin{array}{l}66 \\
20 \\
86\end{array}$ & $\begin{array}{l}97,1 \% \\
29,4 \% \\
63,2 \%\end{array}$ & $\begin{array}{r}2 \\
48 \\
50\end{array}$ & $\begin{array}{r}2,9 \% \\
70,6 \% \\
36,8 \%\end{array}$ & $\begin{array}{r}68 \\
68 \\
136\end{array}$ & $\begin{array}{l}100 \% \\
100 \% \\
100 \%\end{array}$ & 0.000 & 79,200 & $\begin{array}{l}17,666- \\
355,072\end{array}$ \\
\hline
\end{tabular}

Pada tabel 1 terlihat bahwa distribusi responden usia terbanyak pada kelompok tidak beresiko dengan kualitas seksual baik 52 (69,3\%), Usia menikah terbanyak pada kelompok usia $<21$ tahun dengan kualitas seksual baik sebanyak 49 $(62,0 \%)$, lama pernikahan terbanyak $<5$ tahun dengan kualitas seksual baik 
sebanyak $50 \quad(58,1 \%)$, jumlah anak terbanyak primipara dengan kualitas seksual baik sebanyak $48 \quad(57,8 \%)$, pendidikan tertinggi pendidikan sedang dengan kualitas seksual baik sebanyak 56 $(65,1 \%)$, pekerjaan tertiggi tidak bekerja dengan kualitas seksual baik sebanyak 48 $(64,9 \%)$ dan jenis KB terbanyak 1 tahun dengan kualitas seksual baik sebanyak 66 (97\%). Nilai $\mathrm{p}$ value untuk usia 0,111 , untuk usia menikah 0,857 , untuk lama pernikahan 0,140, untuk jumlah anak 0,144 , untuk pendidikan 0,800 , untuk pekerjaan 0,723. Dari karakteristik responden hanya satu yang berhubungan yaitu jenis $\mathrm{KB}$ dengan nilai $\mathrm{p}$ Value 0,000 dimana nilai tersebut $<\mathrm{P}$ value 0,1 hal ini berarti $\mathrm{H} 0$ ditolak dan $\mathrm{Ha}$ diterima sehingga dapat disimpulkan bahwa ada hubungan jenis $\mathrm{Kb}$ dengan kualitas seksual pada wanita akseptor KB hormonal dengan $\mathrm{KB}$ non-hormonal.

Tabel 2. Distribusi Jenis Kontrasepsi pada Wanita Akseptor KB Hormonal dengan Non-Hormonal

\begin{tabular}{lcccc}
\multicolumn{1}{c}{ Jenis Kontrasepsi } & N & & $\begin{array}{c}\text { OR } \\
(\mathbf{9 0 \%} \mathbf{C l})\end{array}$ & p-value \\
\hline - Non-hormonal & & & & \\
- IUD/AKDR & 50 & $36,8 \%$ & 0.013 & 0,000 \\
$\begin{array}{l}\text { - Metode Sederhana dengan Alat } \\
\text { - Metode Sederhana Tanpa Alat }\end{array}$ & 15 & $11 \%$ & $0,005-0,033$ & \\
- Hormonal & 3 & $2,2 \%$ & & \\
$\begin{array}{l}\text { - Suntik } \\
\text { - Implant }\end{array}$ & 42 & $30,9 \%$ & & \\
\hline \multicolumn{1}{c}{ Total } & 26 & $19,1 \%$ & \\
\hline
\end{tabular}

Pada tabel 2 dapat dilihat bahwa distribusi responden berdasarkan jenis metode kontrasepsi yang digunakan oleh wanita akseptor $\mathrm{KB}$ yaitu pada akseptor $\mathrm{KB}$ non-hormonal sebagian besar responden menggunakan metode kontrasepsi IUD/AKDR yaitu sebanyak 50 responden $(36,8 \%)$ sedangkan pada akseptor KB hormonal sebagian besar responden menggunakan metode kontrasepsi suntik yaitu sebanyak 42 responden $(30,9 \%)$.dengan nilai $\mathrm{p}$ Value 0,000 dimana nilai tersebut $<\mathrm{P}$ value 0,1 hal ini berarti $\mathrm{H} 0$ ditolak dan Ha diterima sehingga dapat disimpulkan bahwa ada perbedaan kualitas seksual pada wanita akseptor KB hormonal dengan KB nonhormonal. Dapat disimpulkan bahwa ada hubungan yang signifikan antara penggunaan jenis $\mathrm{KB}$ dengan kualitas seksual pada wanita akseptor KB. 
Tabel 3.Perbedaan Kualitas Seksual pada Wanita Akseptor KB Hormonal dengan Non-Hormonal

\begin{tabular}{|c|c|c|c|c|c|}
\hline \multirow[b]{2}{*}{ Kualitas Seksual } & \multicolumn{2}{|c|}{ Jenis KB } & \multirow[b]{2}{*}{$\begin{array}{c}\text { Total } \\
\%\end{array}$} & \multirow[b]{2}{*}{$\begin{array}{c}\text { OR } \\
(90 \% \mathrm{CI})\end{array}$} & \multirow[b]{2}{*}{$p$-value } \\
\hline & $\begin{array}{c}\text { Non-Hormonal } \\
\mathrm{N}\end{array}$ & $\begin{array}{l}\text { Hormonal } \\
\%\end{array}$ & & & \\
\hline Baik & 66 & $97,1 \%$ & $29,4 \%$ & 0.013 & 0,000 \\
\hline Sedang & 2 & $2,9 \%$ & $70,6 \%$ & $0,005-0,033$ & \\
\hline Jumlah & 68 & $100 \%$ & $100 \%$ & & \\
\hline
\end{tabular}

Berdasarkan tabel 3 didapatkan hasil analisis menggunakan Chi Square dengan metode Continuity Correction, terdapat perbedaan antara penggunaan jenis $\mathrm{KB}$ dengan kualitas seksual pada wanita akseptor KB di wilayah Desa Golong, Kec. Narmada, Lombok Barat bahwa ada sebanyak 66 orang $(97,1 \%)$ responden yang menggunakan $\mathrm{KB}$ non-hormonal memiliki kualitas seksual baik sedangkan diantara wanita akseptor $\mathrm{KB}$ hormonal, terdapat 48 orang $(70,6 \%)$ responden yang memiliki kualitas seksual kategori sedang.

Hasil uji statistic menggunakan SPSS for Windows 2019 diperoleh nilai $\mathrm{P}$ $=0,000$ dimana nilai tersebut $<\mathrm{P}$ value 0,05 hal ini berarti $\mathrm{H} 0$ ditolak dan $\mathrm{Ha}$ diterima sehingga dapat disimpulkan bahwa ada perbedaan kualitas seksual pada wanita akseptor KB hormonal dengan KB non-hormonal. Hasil ini memiliki arti ada hubungan signifikan antara penggunaan jenis $\mathrm{KB}$ dengan kualitas seksual pada wanita akseptor KB. Hasil analisis odd ratio (OR) pada data yang telah diperoleh, dihasilkan pula nilai $\mathrm{OR}=0.013$. Arti dari nilai tersebut yaitu wanita akseptor KB non-hormonal memiliki insiden 0.013 kali untuk bisa memiliki kualitas seksual dalam kategori sedang hingga buruk.

\section{PEMBAHASAN}

Hasil penelitian ini menunjukan adanya perbedaan kualitas seksual pada akseptor $\mathrm{KB}$ hormonal dengan $\mathrm{KB}$ nonhormonal di wilayah Desa Golong, Kec. Narmada, Lombok Barat. Penggunaan jenis $\mathrm{KB}$ mempengaruhi kualitas seksual pada akseptor KB tersebut.Hal ini dikarenakan efek samping masing-masing dari metode kontrasepsi berbeda-beda. Menurut teori Irianto, (2014), yang menyatakan bahwa kontrasepsi yang mengandung hormon progesterone memiliki efek samping penuluran libido seksual, hal ini mempengaruhi kualitas kehidupan seksual pasangan.

Hasil ini sejalan dengan teori menurut Damailia \& Saadati (2016) dalam penelitian yang dilakukan oleh Karimah, $d k k$ (2019), yang menyatakan bahwa efek samping dari pemakaian KB hormonal adalah penurunan libido seksual pada akseptor KB yang dapat menurunkan frekuensi hubungan seksual akseptor KB dan menyebabkan terjadinya penurunan kualitas seksual seseorang. Hasil penelitian ini juga sejalan dengan hasil penelitian yang dilakukan oleh Yosin et al., (2016), ada hubungan bermakna antara efek samping penggunaan kontrasepsi hormonal dengan kualitas kehidupan seksual pada wanita usia subur di Kabupaten Jombang. Penggunaan kontrasepsi hormonal dapat menyebabkan terjadinya disfungsi seksual pada bagi penggunanya hal ini dikarenakan oleh kandungan hormon yang terdapat didalamnya. 
Hasil penelitian ini juga didukung oleh penelitian yang dilakukan oleh Ekaratni \& Wilopo(2006) di Purworejo yang menunjukan sebanyak $65,6 \%$ dari $75 \%$ pengguna kontrasepsi hormonal mengalami hasrat seksual disorder atau penurunan libido seksual. Efek samping dari hormon progesterone yang ada dalam kontrasepsi hormonal berfungsi untuk mengentalkan lendir dalam serviks dan mengurangi kemampuan rahim untuk menerima sel telur yang telah dibuahi, sehingga efek sampingnya adalah penurunan aktivitas seksual (Suratun, Tien, \& Rusmiati, 2008).

Hasil penelitian ini juga sejalan dengan penelitian yang dilakukan oleh Liufeto et al., (2017) yang menunjukan bahwa tidak ada pengaruh penggunaan kontrasepsi non-hormonal (IUD/AKDR) terhadap aktivitas seksual pada wanita akseptor kontrasepsi tersebut. Hasil penelitian ini juga didukung oleh teori oleh Manuaba (2010), yang menyatakan KB non-hormonal tidak mengandung hormone didalamnya. Sehingga penggunaan $\mathrm{KB}$ non-hormonal tidak menyebabkan terjadinya ketidakseimbangan hormonal dalam tubuh akseptor KB non-hormonal tersebut dan tidak menyebabkan penurunan libido pada penggunanya.

Karakteristik usia responden yang berada pada rentang 20-30 tahun merupakan rentang usia yang diklasifikasikan sebagai usia dewasa muda. Penelitian ini sesuai dengan penelitian yang dilakukan oleh Yosin et al., (2016), yang menyatakan bahwa Wanita Usia Subur (WUS) memiliki hubungan dengan kehidupan seksual, meningkatnya umur pada wanita usia subur akan berpengaruh pada kehidupan seksualnya. Hasil penelitian ini juga sejalan dengan penelitian yang dilakukan oleh (Batlajery et al., (2015), yang menyatakan bahwa wanita yang keadaan organ reproduksinya akan berfungsi dengan baik adalah antara usia 20-45 tahun. Setelah Wanita Usia Subur (WUS) memiliki usia diatas 50 tahun, dapat terjadi masalah dalam hubungan seksual dikarenakan wanita pada usia 50 tahun akan mengalami masa menopause dimana pada fase adalah fase berakhirnya siklus menstruasi secara alami.

Bila menopause sudah dialami oleh seorang wanita maka efek samping yang dirasakan adalah menurunnya libido seksual atau gairah seksual. Menurut Palupi et al., (2013), secara fisiologis wanita yang sudah menopause mengalami penurunan fungsi hormonal yang menyebabkan terjadi beberapa perubahan pada respon seksual wanita tersebut. Perubahan tersebut juga menyebabkan ketidaknyamanan saat berhubungan seksual yang berakibat ketidakpuasan seksual pada wanita menopause.

Menurut teori dari Orbuch, (2009), wanita pada usia 20-30 tahun memiliki rasa percaya diri yang tinggi akan kehidupan seksualnya, menemukan kenyaman dan kenikmatan seksual dengan pasangannya. Pada usia ini juga wanita cenderung yakin bisa memberikan kepuasan saat melakukan hubungan seksual. Pada fase usia ini juga wanita cenderung lebih terbuka dan menerima perhal hubungan seksual dengan pasangannya. Teori dan hasil penelitian diatas menguatkan hasil penelitian yang menunjukkan bahwa pemakaian KB mempengaruhi kualitas seksual pada pasangan keluarga.

Hasil penelitian ini sejalan dengan penelitian yang dilakukan oleh penelitian oleh Sulistyawati (2018), dengan hasil 
penelitian yang menunjukan bahwa sebagian besar responden akseptor kontrasepsi non-hormonal mengalami penurunan libido sebanyak 4 orang responden $(7 \%)$ sedangkan akseptor yang tidak mengalami penuruan libido sebanyak 51 orang responden (93\%). Hasil penelitian ini sesuai dengan teori Proverawati (2010), yang menyatakan bahwa kontrasepsi non-hormonal tidak mempengaruhi hubungan seksual.

\section{KESIMPULAN DAN SARAN}

Terdapat perbedaan yang signifikan pada kualitas seksual antara wanita akseptor KB hormonal dengan nonhormonal di wilayah Desa Golong, Kec. Narmada, Lombok Barat. Kesimpulan ini didukung adanya data sebanyak 66 orang $(97,1 \%)$ responden yang menggunakan KB non-hormonal memiliki kualitas seksual baik, sedangkan diantara wanita akseptor KB hormonal, terdapat 48 orang $(70,6 \%)$ responden yang memiliki kualitas seksual kategori sedang. Hal ini menunjukan kualitas seksual akseptor KB non-hormonal lebih baik dari pada akseptor KB hormonal.

Bagi seluruh unsur terkait untuk terus melakukan edukasi tentang berbagai jenis alat kontrasepsi, membuka lembaga konseling $\mathrm{KB}$, untuk pengguna $\mathrm{KB}$ sesuai dengan kebutuhan penggunan. Selain itu peran petugas $\mathrm{KB}$ di lapangan harus dioptimalkan menjadi Pembina Pokja Kampung KB di Desa-Desa. Pembaruan Media Pembelajaran dan Informasi tentang KB melalui aplikasi gadget.

DAFTAR RUJUKAN

Batlajery, J., Hamidah, H., \& Mardiana, M. (2015). Penggunaan Metode Kontrasepsi Suntikan Dmpa Berhubungan Dengan Disfungsi
Seksual Wanita Pada Akseptor Kb Suntik. Jurnal Ilmu Dan Teknologi Kesehatan, 2(2), 49-56.

BKKBN. (2018). Laporan Hasil Pelayanan Kontrasepsi. BKKBN.

Damailia, H. T., \& Saadati, K. (2016). Hubungan Lama Pemakaian Kb Suntik DMPA (Depo Medroxyprogesterone Acetate) Dengan Penurunan Libido Pada Akseptor KB DMPA. Bhamada: Jurnal Ilmu Dan Teknologi Kesehatan (E-Journal), 7(2), 11.

Ekaratni, M. J. A., \& Wilopo, S. A. (2006). Risiko Disfungsi Seksual Pada Perempuan Pemakaian Kontrasepsi Medroxy Progesterone Acetate Di Kabupaten Purworejo. [Yogyakarta]: Universitas Gadjah Mada.

Irianto, K. (2014). Pelayanan Keluarga Berencana: Dua Anak Cukup: Kontrasepsi Untuk Mencapai Target Keluarga Berencana Global. Alfabeta.

Karimah, I. N. (2019). Perbedaan Kontrasepsi Hormonal Suntik Dmpa Dan Pil Kombinasi Dengan Penurunan Gairah Seksual Akseptor $\mathrm{Kb}$ Di Wilayah Kerja Puskesmas Pekauman Kota Banjarmasin Tahun 2019. Journal of Midwifery and Reproduction, 3(1), 21-28.

Katmini, K. (2020). Determinan Kesehatan Ibu Hamil Tentang Tanda Bahaya Kehamilan dengan Pencapaian Kontak Minimal 4 Kali Selama Masa Kehamilan (K4) 
Katmini $1 * 1$. Jurnal Kebidanan Dan Kesehatan Tradisional, 5(1), 29-35.

Liufeto, K. G., Wahab, A., \& Emilia, O. (2017). Penggunaan Intra Uterin Device (IUD) Dan Pola Aktivitas Seksual Pada Perempuan Di Kupang. Berita Kedokteran Masyarakat, 33(5), 243-248.

Manuaba, I. B. G. (2010). Ilmu Kebidanan, Penyakit Kandungan dan Keluarga Berencana. Jakarta: EGC, $15,157$.

Masnun. (2019). Ketika NTB Darurat Kekerasan Terhadap Perempuan. Ataranews (9 Maret).

Millheiser, L. S., Helmer, A. E., Quintero, R. B., Westphal, L. M., Milki, A. A., \& Lathi, R. B. (2010). Is infertility a risk factor for female sexual dysfunction? A case-control study. Fertility and Sterility, 94(6), 20222025.

Orbuch, T. L. (2009). 5 Simple Steps to Take Your Marriage from Good to Great. Delacorte Press.

P2TP2A. (2017). P2TP2A (2017). Data Statistic Kasus KDRT Provinsi NTB. Dokumentasi (Mataram: P2TP2A Provinsi Nusa Tenggara Barat, 2017). P2TP2A Provinsi Nusa Tenggara Barat.

Pakpour, A. H., Zeidi, I. M., Saffari, M., \& Burri, A. (2013). Psychometric Properties Of The Iranian Version Of The Sexual Quality of Life Scale Among Women. The Journal of
Sexual Medicine, 10(4), 981-989.

Palupi, P., Afiyanti, Y., \& Rachmawati, I. N. (2013). Pengalaman Seksualitas Perempuan Menopause. Jurnal Keperawatan Indonesia, 16(1), 1-10.

Pratiwi, R. H. (2018). Pernikahan Usia Dini Pada Masyarakat Perkotaan (Studi Kelurahan Segalamider Kecamatan Tanjungkarang Kota Bandar Lampung).

Profil Kesehatan NTB. (2018). Profil Kesehatan NTB. Dinas Kesehatan NTB.

Proverawati, A., Islaely, A. D., \& Aspuah, S. (2010). Panduan Memilih Kontrasepsi. Yogyakarta: Nuha Medika.

Sari, A. A., \& Sularto, R. B. (2019). Kebijakan Formulasi Kekerasan Seksual Terhadap Istri (Marital Rape) Berbasis Keadilan Gender Di Indonesia. Jurnal Pembangunan Hukum Indonesia, 1(1), 117-127.

Semararatih. (2010). Hormon Reproduksi Wanita. Pustaka Mandiri.

Shahraki, Z., Tanha, F. D., \& Ghajarzadeh, M. (2018). Depression, sexual dysfunction and sexual quality of life in women with infertility. BMC Women's Health, 18(1), 1-4.

Sulistyawati, A. (2018). Hubungan Jenis Alat Kontrasepsi Dengan Gangguan Kesehatan Reproduksi.

Suratun, S., Tien, H., \& Rusmiati, S. (2008). Pelayanan Keluarga 
Berencana Dan Pelayanan

Kontrasepsi. Jakarta: Trans Info Media.

Yosin, E. P., Mudigdo, A., \& Budihastuti, U. R. (2016). Effect of Hormonal Contraceptive on Sexual Life, Body Mass Index, Skin Health, and Uterine Bleeding, in Women of Reproduction Age in Jombang, East Java. Journal of Maternal and Child Health, 1(3), 146-160. 